\title{
INTRODUCTION TO INNOVATION RESEARCH IN HEALTH AND WELLNESS TOURISM
}

\author{
AleKSANDER PANASIUK, ${ }^{1}$ EUGENIA PANFILUK, ${ }^{2}$ ELŻBIETA SZYMAŃSKA ${ }^{3}$
}

RECEIVED

ACCEPTED

JEL

CLASSIFICATION

KEYWORDS

ABSTRACT

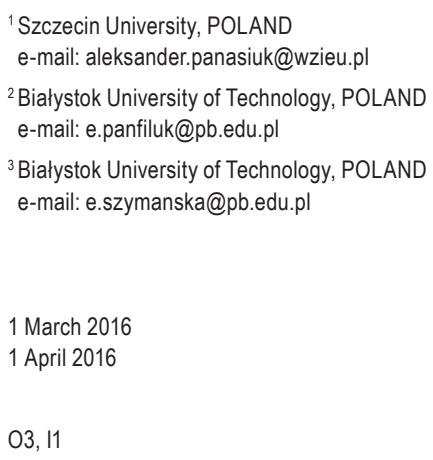

03, I1

innovation, tourism market, health and wellness tourism, health resort tourism

This article focuses on the concept of research on the innovation of health and wellness tourism market. The objective of this paper is to present methodological concept for research on innovation of health and wellness tourism entities in Poland. The theoretical section includes the presentation of innovation as a concept, as well as its relation to the tourism market and health and wellness tourism market. The subjective and objective scope of health and wellness tourism market has been determined. It allows singling out entities which undertake activities focused on providing innovation on the health and wellness tourism market. This study includes presentation of methodology for empirical innovation research in health and wellness tourism, as well as specification of the scope of research, stages, methods and expected results.

\section{Introduction}

The notion of innovation is deeply rooted in the economy and additionally it is broad and complex. Innovation processes are a vital instrument for market development, including vertical markets. Health and wellness tourism is a significant and constantly developing branch of the tourism market. To this form of tourism corresponds an offer resulting from an operation of entities from the broadly-seen tourism market, as well as a specialized offer 
that reflects the needs of tourists involved in health and wellness tourism, including the health resort segment. Innovations present an opportunity for service providers on the health and wellness market to have a competitive advantage and give them a more effective method of reaching consumers (patients, spa clients, tourists) with their offer. The aim of this study is to present a methodological concept for innovation research of health and wellness tourism entities in Poland.

\section{Innovation and its types}

Innovations are an important factor for shaping and developing modern markets. According to traditional views on the notion of innovation formulated by J. Schumpeter (1960) in relation to the functioning of the market, the term innovation means a combination of following factors, with their functional interdependencies:

- launching new products or improving existing ones,

- implementing new or improved production technology, including new methods of providing services,

- introducing new ways of selling and buying, including new ways of creating interaction with customers, together with appropriate customer care systems,

- opening a new market, both in terms of supply, production or sales,

- using new raw materials, materials and tools,

- implementing changes in the organization of production, including changes in the organization of the service providing process (Filipiak, Panasiuk, 2008).

Innovations are one of the key elements of increasing competitiveness and achieving market success in the knowledge-based economy. When taken in a general view, one may regard innovation as a process of introducing new products, ideas or way of acting. Thus, these would include all positive implemented changes, which are perceived as new from the perspective of the entity that introduced them (Kalinowski, 2010). Innovations are connected with creating new market offers. However, normally these are not completely new products but rather improvements of already existing products (Westland, 2008), which are given new practical values or increased quality parameters. Thus, vast majority of innovations consists in creative imitation of already existing solutions. Creative imitation focuses particularly on the consumer needs and starts not from observing the product but the market (Drucker, 2000).

As aspects of innovation in the service sector became part of the research interest, the issues of innovation became even more complex. This is a result of the fact that from the theoretical and practical perspectives innovation is focused not just on technology and physical aspects of products but also included aspects of nonphysical products, i.e. services. Thus, service innovations are a result of change process or are a process itself that is connected to the product of a non-physical nature which characteristic is having direct contact between service providers and clients (Kupper, 2001). Typical innovative behaviours in terms of services include:

- creating new service concepts,

- new forms of cooperation with the client,

- new systems for providing services,

- using modern IT solutions (Den Hertog, 2002).

Innovative actions should be based on organized work, of a collective nature, that combines particular processes (Wiatrak, 2011). Following types of innovation can be distinguished as a result of introducing new concepts for business operation on the market: 
- product,

- process,

- organizational (managerial),

- marketing (Niedzielski, 2013),

- institutional (Hajalager, 2010).

The first two types mainly refer to core business operation of an enterprise that is to the structure of the offer. Market expansion should be the result of product innovation and this in turn should lead to the development or diversification of offered products in order to fully satisfy clients' needs and requirements. Process innovation refers to changes in the creation process and in the methods of delivering products. Organizational innovations are related to internal organization and have definitely a non-physical character. They are mostly aimed at changes in the methods of operations, including creating new organizational structures, implementing new management techniques and changes in economic practices, both internally and externally. A similar non-physical character defines marketing innovations as they focus on the course of action and interaction between the organization and the client. Their objective is to increase the demand for products, both these already on offer and the ones being launched on the market (including the existing ones that were modified). In this respect, an emphasis is put on aggressive and creative promotion, finding its more effective form or introducing new methods of reaching potential buyers with some incentive, which has not been used by the entity yet (Hejduk, 2004; Kalinowski, 2010). Institutional innovations refer to new forms of collaboration between market participants or changes in the legal form of business operation of an entity.

\section{Innovations on the tourism market}

Innovation may be directly applied to the tourism market on which a key role is played by upholding sustained competitive advantage by entities from the supply side of the market. The ongoing globalization processes demand not only increased innovation activity from tourism enterprises but also from tourist destination as it determines their survival and further growth and development. Business operation of entities on the tourism market impose the necessity to develop different types of innovations complementarily (Gołembski, 2007), as tourism enterprises (mainly micro, small and medium) vary in terms of their level of innovation, which, among others, depends on the business strategy used, type of business, staff qualifications and market environment (Gancarczyk, 2012).

The innovation of tourism enterprises is determined by independent actions of these entities but also by sources of innovation that come from: suppliers, competitors, employees, consumers (Peters, Pikkematt, 2005), advisory and consultancy firms (Wszendybył-Skulska, 2010), tourism policy entities. The actions of tourism policy entities may be a source of innovation for tourism entities by developing a pro-innovation policy aimed at the tourism market, in particular at tourism entrepreneurs. Furthermore, tourism policy entities may conduct innovative actions on their own. It should be noted that one of the main means of introducing innovation to the operations of tourism market entities are information technologies (Prahalad, Krishnan, 2010). A basic way of developing innovation on the tourism market and the evaluation of the impact of innovation on its structure is referring to the classification of innovation types and indication of their aspects in the operation of particular types of entities from the supply side of the tourism market.

Product innovations consist in creating new products or improving already existing ones by giving them new practical values or increasing quality parameters. It is very challenging for tourism industry entities to present 
a tourism offer with completely new tourism products. A tourism entrepreneur may direct his actions on reconstructing a comprehensive service offer by using new knowledge about competition's offers (Szymańska, 2013) and being aware of new consumer purchasing preferences. With regards to health resort enterprises, for example, this may include new treatment profiles and corresponding services offered in a form of package.

In terms of process innovation related to the improvement of efficiency of service operations and changes in the ways of delivering offers and consumer service, we may point to the implementation of previously unused modern medical technologies in health resort enterprises.

Organizational (managerial) innovations include new forms of operation and organization of collaboration inside an entity. On the level of health resort tourism destinations, it may include the coordination of operation of entities that develop health and wellness tourism offer.

Marketing innovations refer to the use of new concepts of conducting marketing activities, in particular the use of marketing instrumentation. These activities in health resort enterprises may consist in the expansion of the offer for the so-called commercial clients. Whereas in health resort tourism destination it may focus on promotion of the area in new geographical markets and promotion aimed at market segments untapped so far.

Institutional innovations involve the creation of new collaboration structures in order to improve the operation of tourism market entities. Health resort tourism destinations may create favourable conditions for the cooperation of tourism entrepreneurs within a tourism area (town/city). This is done in order to develop a joint offer aimed at inbound tourism movement and to improve the use of EU funds for the development of service potential and offer (Panasiuk, 2013), as well as to make entities of the supply side of the market collaborate in terms of creating common information system, tourism promotion and service sales.

Presented examples show selected areas where innovation on the health resort tourism market has been used. The listed solutions on the supply side of the market influence or may influence the structure of service offer, way of reaching the consumer with an offer and above all determine the structure of tourism offer consumption.

As mentioned and presented above, innovation processes on the tourism market stem not only from the active participation of tourism entrepreneurs but they also concern tourist destinations. Tourist destinations are directly connected to the public system (local authorities) and implement tasks related to the tourism policy. The entities representing public authorities impact innovation through developing a network of connections between entrepreneurs and tourism organization from an area which has tourist values and attractions, tourism infrastructure and where tourism services are provided. The public entities' role in a tourism area is to establish an optimal, under specific circumstances, configuration of competitive advantages (Jaremen, Rapacz, Gryszel, 2010) and in a result to implement the innovation policy (Panasiuk, 2014).

\section{Health and wellness tourism market}

One of the tourism markets is the health and wellness tourism market. This market is distinguished in terms of reasons for tourism, i.e. trips which main or complementary aim is to improve health and physical and mental condition of a tourism participant. This market includes health and wellness tourism connected with the prevention and improvement of health (wellness \& spa, aesthetic medicine, a part of health resort tourism) and health and wellness tourism connected with medical treatment (medical tourism, a part of health resort tourism) (Szymańska, 2012). 
The health and wellness tourism market is also a special industry encompassing in its activities elements of other tourism industries, mainly the hotel industry, however, with an equal involvement of medical industries, i.e. medical treatment, including wellness.

In terms of the market share and current development of health and wellness tourism, the segment of health resort tourism should be considered as most important. A special nature of health resort tourism mainly results from an aim of and reason for a trip to a place acknowledged as a health resort as well as from needs to use services provided by health resort enterprises.

The main reasons for health resort tourism include: regeneration, improvement of health and well-being, active leisure (Gaworecki, 2000). The listed aims may be achieved not only in health resort tourism, but also, for example, in active tourism or tourism connected with staying in one place (Panasiuk, 2008). It should be remembered that, as far as demand is concerned, a health resort tourist creates also other needs which are satisfied by the other elements of the tourism supply structure.

Health resort tourism is described as trips connected with spa, rehabilitation and health resort treatment related to natural healing provided in accordance with a consultation with a health resort doctor (Januszewska, 2004). It should be emphasised that a basis for health resort tourism is health resort treatment which is not only a field of medicine, but also constitutes an essential component of tourism economy. Health resort treatment takes place in natural healing units where patients benefit from treatment based on using natural resources (health resort resources) which include curative waters, mud or gases. An important component of health resort treatment is staying in a place which is characterized by a local curative climate. The role of health resorts is not only to treat patients, but also to remember about prevention in their health-oriented activities (Bańkowska, 1999).

Kaspar and Fehrlin (1979) suggest that health resort tourism be described as relationships, activities and phenomena which result from stays of people having medical treatment reasons and from travels to health resorts and returns to their places of living (Kornak, 1999). Then, this definition serves as the basis for defining the essence of the health resort tourism market and, next, indicating its elements of the subjective and objective structure. In objective terms, the health resort tourism market is a process in which customers (health resort tourists) and service providers (providers of tourism and medical services and health resort tourism destinations - i.e. health resorts) specify the subject of the market exchange which constitutes services in a health resort, and prices and conditions under which they want to sell and purchase them (Panasiuk, 2011). The health resort tourism market defined in such a way and being the element of the tourism market has two fundamental functions:

- treatment, rehabilitation and prevention,

- recreation.

By means of the listed functions, offers of the health resort tourism market (tourism and medical ones) merge with offers directed at demand satisfied by the other tourism markets, e.g. recreational, sightseeing and qualified tourism. Then, health resort tourism exists thanks to connecting medical and preventive functions with a tourism function (Dryglas, 2006).

Taking the spatial aspect of health resort tourism into account, it should be emphasised that it takes place in an area defined as a health resort. The Act of 28 July 2005 on Health Resort Treatment, Health Resorts and Health Resort Conservation Areas and on Health Resort Municipalities (Ustawa..., 2005) defines a health resort as an area which has been given the status of a health resort, where health resort treatment is conducted and which is marked off in order to use and protect natural resources existing there (Lewandowska, 2007). 
The main entities operating on the health resort tourism market are:

a) in terms of demand:

- health resort tourists (patients),

- other tourists (not patients) staying in a health resort and using health resort offers as complementary services;

b) in terms of supply:

- health resort enterprises (health resort treatment units, e.g. sanatoriums, natural healing units, wellness \& spa centres),

- other tourism enterprises offering their services to both patients and other tourists,

- enterprises offering tourists, including patients, paratouristic services which main function is to satisfy needs of permanent inhabitants of a health resort;

c) in terms of the tourism policy:

- authorities regulating the functioning of health resort treatment and the functioning of tourism economy,

- local authorities of health resorts as well as their associations (Association of Polish Spa Communities),

- trade organizations of the subjects of health resort business (Chamber of Commerce "Uzdrowiska Polskie")

- tourism organizations.

It should be noted that the health resort tourism market can be developed mainly thanks to the supply elements of the general tourism market. It is complemented by elements relevant to the reasons for health resort tourism, that is by those resulting mainly from activities of sanatoriums or health resort hospitals constituting a special type of health resort accommodation facilities. The reasons typically connected with health resort tourism movement include treatment and rehabilitation. The other listed examples of reasons for tourism are analogical as in the case of reasons of other tourists in health resorts. Typical elements of supply on the health resort tourism market include functioning of health service (as an element of the medical services market) and functioning of health resort units (as a form of activities including both the medical service market and the tourism service market). Such aspects as: exploitation of health resort resources (e.g. brine, mud), activities of wellness \& spa centres and local health resort infrastructure (e.g. mineral water pump rooms, spa centres), apart from mainly influencing demand from patients, they have also an impact on demand from tourists arriving to health resorts for other reasons; and the listed elements of the supply structure satisfy their needs for complementary services.

\section{Methodological aspects of the research on health and wellness tourism innovation}

The research on innovation in health and wellness tourism constitutes the objective of the intercollegiate research project funded by the National Centre of Science and conducted by Elżbieta Szymańska, from the Bialystok University of Technology. The main objective of the research project is to expand knowledge of primary research through devising a theoretical model for assessment of innovation of entities providing services in health and wellness tourism, including health resort tourism, and describing factors influencing innovation. This is important in the context of:

- issues of extension of life span and the aging society,

- a dynamic growth of health and wellness tourism movement,

- possibilities of funding development of supply on this market thanks to the EU funds. 
The research involves health and wellness tourism in a broad sense together with an offer of medical and health resort tourism, aesthetic medicine and wellness \& spa.

Effects of innovative activities in health and wellness tourism are difficult to define and assess. Innovations are introduced by many entities making up the health and wellness tourism market in terms of supply, i.e. mainly:

- direct providers of health services connected with health care (e.g. hospitals, health resort units, medical offices),

- direct providers of tourism services (e.g. travel agencies, hotels, carriers, wellness \& spa centres),

- entities indirectly satisfying needs of health and wellness tourists in tourism reception areas (e.g. recreation, culture, entertainment, trade and services),

- municipalities (towns) having the status of a health resort, developing a regional tourism offer, giving an opportunity to use health resort resources and maintaining and developing tourism and health resort local infrastructure.

In order to conduct the research on innovation in health and wellness tourism, the scope of research hypotheses has been specified:

1. The most common forms of innovations in health and wellness tourism are product innovations. These innovations are introduced by all entities making up the health and wellness tourism market in terms of supply, mainly enterprises as well as public institutions.

2. The model of innovation of health and wellness tourism is coherent with the concept of open innovation. Using open innovations can result from access to knowledge of innovations in the health and wellness tourism market and the tourism and medical markets, as well as from using analogy method and adapting to the range of applications in health and wellness tourism and other fields of economy.

3. The main determinant of innovation in health and wellness tourism in Poland is a possibility of getting the EU funds for innovative projects. The possibility of using the EU funds concerns the programming period 2014-2020 in the European Union.

The necessary research methods to be used in the research include:

- a comprehensive critical overview of literature sources concerning innovation in economics, health and wellness tourism, innovation in tourism, factors determining innovations in health and wellness tourism,

- the Delphi method addressed to representatives of tourism sciences dealing with issues of the functioning of the health and wellness tourism market; the research will enable identifying the range of indicators used in research on health and wellness tourism innovation,

- a diagnostic survey, by using a questionnaire among health and wellness tourism entities on the basis of a representative sample of entities from all Polish regions,

- case studies, by presenting best practices in health and wellness tourism innovation, which will concern the most innovative entities and innovative projects on the analysed market.

The research project and devising the research procedure and methodology are based on international models, especially on research conducted in Finland and Hungary. The conducted research is novel. The result of the conducted studies of literature sources is that there is a lack of sources concerning, in particular adaptation of innovation theories to the field of health and wellness tourism, especially issues of the classification of innovations and the structure of entities undertaking pro-innovative activities. The secondary sources also lack studies concerning the role of local government units (i.e. health resort municipalities) in activities aimed at innovation of 
health resort tourism. Therefore, the research is comprehensive. Among others, the classification of innovations in health and wellness tourism in objective and subjective terms will be presented.

The research has been divided into the following stages:

1. Theory overview.

2. Methodology selection.

3. The specification of rules on research methodology, the choice and prioritization of factors determining innovation of health and wellness tourism.

4. The study of methodology of research on innovation in health and wellness tourism.

5. The identification of best practices.

6. The development of an innovation model for health and wellness tourism.

\section{The expected results of the research on health and wellness tourism innovation}

Thanks to the conducted research, it will be possible to: make theoretical assumptions to the innovation research in health and wellness tourism, identify assumptions to the assessment of innovations developed in entities offering services in health and wellness tourism, identify factors of health and wellness tourism innovation, indicate determinants of innovation in health and wellness tourism in Poland, present best practices in innovation in all health and wellness tourism areas.

The results of the project can be divided into direct and indirect ones. The direct results of the project include devising a model of health and wellness tourism innovation together with the identification of innovation types in entities providing services in health and wellness tourism and the identification of factors of health and wellness tourism innovation.

The indirect results of the research encompass: applying the devised methodology to the practical identification of innovations in health and wellness tourism, indicating possible fields where the EU funds can be used in health and wellness tourism in the financial perspective 2014-2020. Moreover, knowledge acquired as a result of the research can be used in further theoretical research on identifying and prioritizing innovations in health and wellness tourism.

\section{Acknowleadlyments}

The project has been financed with the resources of the National Science Centre granted on the basis of the decision No. DEC-2013/11/B/HS4/02138.

\section{References}

Bańkowska, E. (1999). Szanse i zagrożenia Sopotu jako miejscowości uzdrowiskowej. In: Turystyka uzdrowiskowa. Stan i perspektywy. Publikacje Wyższej Szkoły Turystyki i Hotelarstwa w Sopocie, Gdańsk.

Den Hertog, P. (2002). Co-producers of innovation: on the role of knowledge-intensive business services in innovation. In: J. Gadrey, E. Gallouj, E. Elgar (eds.), Productivity, innovation and knowledge in services. New economic and socio-economic approaches, MA, Cheltenham-Northampton.

Drucker, P. (2000). Myśli przewodnie Druckera. Warszawa: MT Biznes.

Dryglas, D. (2006). Kształtowanie produktu turystycznego uzdrowisk w Polsce. Kraków: Uniwersytet Jagielloński.

Filipiak, B. \& Panasiuk, A. (eds.) (2008). Przedsiębiorstwo usługowe. Zarządzanie. Warszawa: Wydawnictwo Naukowe PWN. Gancarczyk, J. (2012). Innowacje w małych i średnich przedsiębiorstwach turystycznych. Ekonomiczne Problemy Usług, 91. Gaworecki, W.W. (2000). Turystyka. Warszawa: Polskie Wydawnictwo Ekonomiczne,. 
Gołembski, G. (ed.) (2007). Przedsiębiorstwo turystyczne. Ujęcie statyczne i dynamiczne. Warszawa: PWE.

Hejduk, I. (ed.) (2004). Przedsiębiorstwo przyszłości. Fikcja i rzeczywistość. Warszawa: Instytut Organizacji i Zarządzania w Przemyśle ORGMASZ.

Hjalager, A-M. (2010). A review of innovation research in tourism. Tourism Management 31 (1), 1-12.

Januszewska, M. (2004). Znaczenie produktu uzdrowiskowego w rozwoju turystyki w Polsce. In: A. Panasiuk (ed.), Markowe produkty turystyczne. Szczecin-Niechorze: Fundacja na rzecz Uniwersytetu Szczecińskiego.

Jaremen, D., Rapacz, A. \& Gryszel, P. (2010). Innowacje a atrakcyjność turystyczna wybranych miejscowości sudeckich. Acta Scientairum Polonorum, Oeconomia, 9 (4).

Kalinowski, T.B. (2010). Innowacyjność przedsiębiorstw a systemy zarządzania jakością. Warszawa: Oficyna.

Kaspar, C. \& Ferlich, F. (1979). Marketing Konzeption der Heilböund Kurorte B16. Hochschule St. Gallen.

Kornak, A.S. (1999). Uzdrowiska polskie w systemie rynku i zarządzania marketingowego. Bydgoszcz: Kujawsko- Pomorskie Studium Edukacyjne.

Kupper, C. (2001). Service innovation. A review of the state of the art. LMU, September.

Lewandowska, A. (2007). Turystyka uzdrowiskowa. Materiały do studiowania. Szczecin: Wydawnictwo Naukowe Uniwersytetu Szczecińskiego.

Niedzielski, P. (2013). Kreatywność i procesy innowacyjne na rynku usług transportowych. Ujęcie modelowe. Szczecin: PTE.

Panasiuk, A. (eds.) (2011), Ekonomika turystyki i rekreacji. Warszawa: Wydawnictwo Naukowe PWN.

Panasiuk, A. (2013). European Union Funds in the Development of Regional Sustainable Tourism Economy in 2007-2013. In 2nd International Scientific Conference Tourism in South East Europe.

Panasiuk, A. (ed.) (2008). Gospodarka turystyczna. Warszawa: Wydawnictwo Naukowe PWN.

Panasiuk, A. (2014). Rynek turystyczny. Studium strukturalne. Warszawa: Difin.

Peters, M., Pikkematt, B. (eds.) (2005). Innovation in hospitality and tourism. New York: Routledge.

Prahalad, C.K., Krishnan, M.S. (2010). Nowa era innowacji. Warszawa: Wydawnictwa Profesjonalne PWE.

Schumpeter, J. (1960). Teoria rozwoju gospodarczego. Warszawa: PWN.

Szymańska, E. (2012). Innowacyjność turystyki zdrowotnej. In: T. Baczko (ed.), Raport o innowacyjności sektora medycznego w Polsce w 2012 roku. Warszawa: Instytut Nauk Ekonomicznych PAN.

Szymańska, E. (2013). Procesy innowacyjne przedsiębiorstw świadczących usługi w zakresie organizacji imprez turystycznych. Białystok: Oficyna Wydawnicza Politechniki Białostockiej.

Ustawa z 28 lipca 2005 roku o lecznictwie uzdrowiskowym, uzdrowiskach i obszarach ochrony uzdrowiskowej oraz o gminach uzdrowiskowych. Dz.U. nr 167 poz. 1399.

Westland, J. (2008). Global innovation management. A strategic approach. New York: Palgrave.

Wiatrak, A.P. (2011). Innovative management in public organizations. Współczesne Zarządzanie, 1.

Wszendybył-Skulska, W. (2010). Źródła innowacyjności w turystyce. Acta Sceintiarum Oeconomia, 9 (4).

Cite this article aS:. Panasiuk, A., Panfiluk, E., Szymańska, E. (2016). Introduction to innovation research in health and wellness tourism. European Journal of Service Management, 18 (2), 23-31. DOI: 10.18276/ejsm.2016.18-03. 
